\title{
LIVEABLE PUBLIC URBAN SPACES: CRITERIA FOR ASSESSMENT AND DESIGN
}

\author{
UDO DIETRICH \& GRETA KIRCHBERG ERTO \\ REAP research group (Resource Efficiency in Architecture and Planning), \\ HafenCity University Hamburg, Gemany
}

\begin{abstract}
Human needs range from subsistence and protection to affection, understanding and participation and finally to leisure, creation, identity and freedom. An essential part of these needs is satisfied in public urban spaces where we watch, communicate, play or just enjoy life. As part of a university course, master students of architecture and urban planning evaluated public urban spaces, which they perceived as positive as well as negative. The goal of this investigation was to identify the specific qualities which create a successful urban space where people love to stay. What qualities do the positive spaces have and what is missing in the negative ones? The students became also aware of the importance of urban spaces and their impact on communities. The results of the analysis of some hundred (mainly European) places are summed up and generalized in a list of criteria for successful urban spaces. This list can be used for assessment and improvement of existing spaces as well as for the design of new ones. It is presented in this paper and explained with the help of some examples and pictures. The list differentiates between primary criteria, the ones that have to be fulfilled as a precondition, and supplementary criteria, the ones that increase the attractiveness of the space. Such a list should be much more focused on social criteria and human needs - what do we want to do and to experience in open spaces? The necessary design to satisfy these wishes will then come as a natural consequence. Furthermore, the list is completed with contemporary criteria like enactment of illumination, events, social media etc.

Keywords: design of public open spaces, livability, human scale, protection, comfort, enjoyment.
\end{abstract}

\section{INTRODUCTION}

Being outdoors is a central part of being human. We enjoy nice weather and adapting to different changing conditions [1]. Public spaces are areas that allow us to communicate with our fellow human beings; to exchange opinions, and to stay for leisure, etc. (Fig. 2).

But who cares for an appropriate design about public spaces in our cities? Architects plan at building scale, while urban planners concentrate on a larger scale. The design of public open spaces is somewhere in between the two of them. As a consequence, the potential of public spaces is often overlooked and they are more or less reduced to (automotive) traffic zones.

Well-designed urban spaces are nowadays not in the focus, whereas modern cities concentrate on real estate. Building construction process is rationalized, the size of buildings growths exponentially and parallel to that the number of unattractive and dysfunctional public spaces. Finally, there are communities where inhabitants spend most of their time indoors and live isolated in their apartments (Fig. 1).

About 1970 first opposing movements and investigations started to bring human scale back to public spaces. A pioneer was Jan Gehl who created a list of 12 quality criteria for good design of public spaces [4], [5].

This paper reports about the use and further development of these criteria in a master course for architecture students. Chapter 2 describes the general task of the students' work. Chapter 3 is about the Gehl's criteria with the original rules for what to do and how to design. 
A very important part of the task was the assessment of the criteria and consequently their further development step by step with each semester.

At the beginning the updated criteria list had the same structure and number of criteria as the original one, but the list of what to do and to design became more and more extended. That version was part of an earlier publication [6].

Thus, during that process it was noted that the structure of the criteria is design oriented and that important social aspects (like access to sanitaria's, possibility to buy food and drinks etc.) are not part of these criteria. A look on the basic human needs appeared as logical, the list created by Max-Neef [7], is presented in chapter 3, too.

As a consequence, the criteria were structured differently in this paper and are based on the human needs. This new list of criteria for assessment and design of public open spaces will be presented in chapters 4 to 8 , supplemented with some selected examples in chapters 9 and 10.

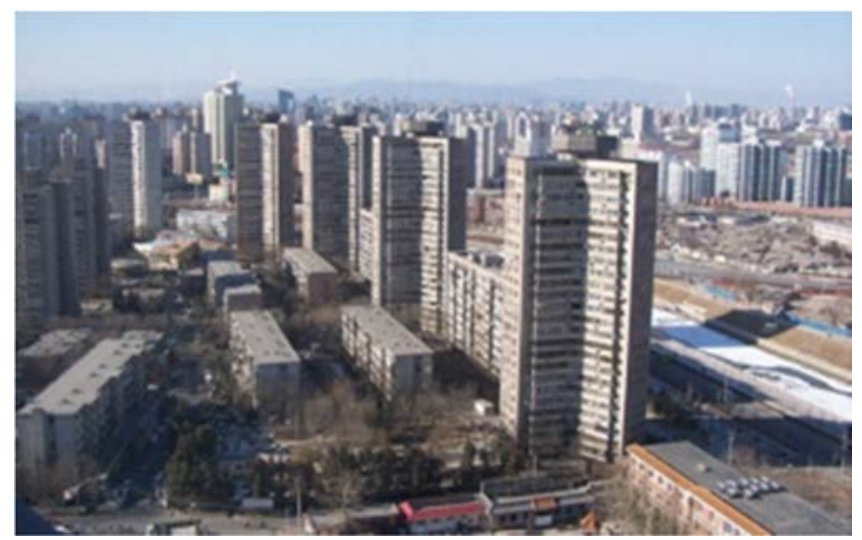

Figure 1: Layout for a complex of apartment towers in Chaoyang District, Beijing, China, leading to dead public spaces, dedicated only to pass through [2].

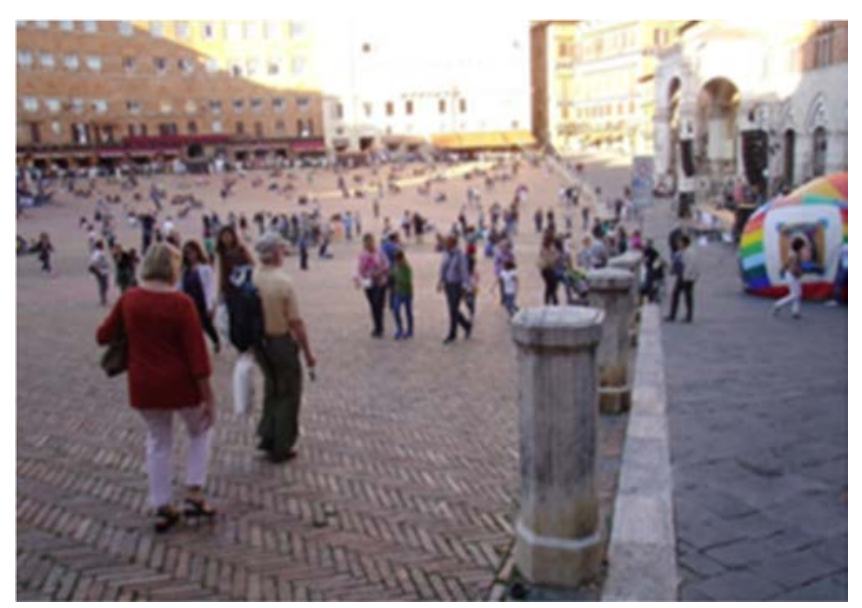

Figure 2: Piazza del Campo in Siena, Italy as an example for a liveable public urban space, full of people enjoying the situation (own photograph) [3]. 


\section{TASK FOR THE STUDENT GROUPS FOR THE ASSESSMENT OF PUBLIC SPACES}

\subsection{Task for the assessment of public urban places}

Students were asked to analyse different public open spaces of their choice. They were to use a given list of criteria (see chapters IV to VIII) as an assessment tool.

- Create a sequence of at least 6 photographs, which represent situations in outdoor urban spaces, on which you react spontaneously very positively or negatively.

- Describe why you perceive the situation as positive/negative. Assess these situations according to the given list with criteria for assessment and design of public urban spaces.

- Derive proposals for improvements of the chosen urban spaces, especially for the negatively felt of course.

- Does the space allow these improvements or does it elude such changes?

2.2 Task for the assessment of the list of criteria for the assessment of public urban places

A second task was to assess the criteria itself and to give proposals for further improvement.

- Are these criteria correct/complete?

- Which one you would delete/change/add?

- Would you use these criteria in your own work?

- Which other experiences you made during the analysis should be mentioned?

Like this, the list was further and further developed over generations of students. Thus, the students started with a previous one that was further developed with their own proposals to the actual one (December 2016).

\section{PRIMAL SOURCES OF THE CRITERIA}

3.1 Jan Gehl's 12 quality criteria for good design of public spaces as starting point Initially the process started with Jan Gehl's 12 criteria [4], [5], Fig. 3.

\subsection{Human needs}

The list of criteria can be better developed if social criteria and human needs are taken as basis.

Following Max Neef [7], the human needs range from subsistence and protection to affection, understanding and participation and finally to leisure, creation, identity and freedom. They can be satisfied by having qualities and quantities, having things, doing actions and social interacting (see Fig. 4). The stay in public urban spaces is connected to a lot of these satisfiers, especially the ones on the lower right section. That helps to understand what we want to do and to experience in public spaces. The necessary design to fulfil these wishes is then a consequence of that.

\subsection{Further sources contemporary life and different cultures}

Furthermore, the list is completed with contemporary criteria like enactment of illumination, events, social media etc. Since the student's groups consisted of several international students, they contributed not only with experiences from local (German) urban spaces but also from other urban spaces mostly in Europe but also around the world. 


\section{LIST OF CRITERIA FOR ASSESSMENT AND DESIGN OF PUBLIC URBAN SPACES - OVERVIEW}

The criteria are a support tool for the analysis and the design process, yet not a universal, strictly to be followed from beginning to end course of action. The underlying social behaviour is therefore too much complex.

The criteria have a different value depending on the analysed rooms, some of them don't even need some criteria (e.g. seats, if the people are standing in front of a bar). Some people can perceive one room as safe, other ones as unsafe. A space can be safe during the day, but unsafe at night, etc. Thus, these criteria are not meant to be static and uniform, but dynamic and to be used each time adapted to the specific situation. Rooms are in an urban and social context, which can contribute crucially to their successful functioning or can also prevent it.

Every space has a more or less sharply defined target group (from a commonly used place, like a harbour pier with excursion boats, to fans in a soccer stadium), on which its efficiency depends. In reverse, a place will have much more success, the better it is specifically designed to fulfil the needs of its target group. So, there may be places which despite negative aspects (e.g. traffic noise) have a high identity and attractiveness for limited target groups and times of the day (night bars at a noisy crossroad, but under a bridge, skate parks, etc.).

\begin{tabular}{|c|c|c|c|}
\hline $\begin{array}{l}\mathrm{P} \\
\mathrm{R} \\
\mathrm{O} \\
\mathrm{T} \\
\mathrm{E} \\
\mathrm{C} \\
\mathrm{T} \\
\mathrm{I} \\
\mathbf{0} \\
\mathrm{N}\end{array}$ & $\begin{array}{l}\text { 1. Protection against } \\
\text { traffic \& accidents } \\
\text { - traffic accidents } \\
\text { - fear of traffic } \\
\text { - other accidents }\end{array}$ & $\begin{array}{l}\text { 2. Protection against } \\
\text { crime \& violence } \\
\text { (feeling of safety) } \\
\text { - lived in/used } \\
\text { - streetlife } \\
\text { - streetwatchers } \\
\text { - overlapping functions } \\
\text { in space \& time }\end{array}$ & $\begin{array}{l}\text { 3. Protection against } \\
\text { unpleasant sense } \\
\text { experiences } \\
\text { - wind/draft } \\
\text { - rain/snow } \\
\text { - cold/heat } \\
\text { - pollution } \\
\text { - dust, glare, noise }\end{array}$ \\
\hline $\begin{array}{l}\mathbf{C} \\
0 \\
\mathbf{M} \\
\mathbf{F} \\
0 \\
\mathbf{R} \\
\mathrm{T}\end{array}$ & $\begin{array}{l}\text { 4. Possibilites for } \\
\text { WALKING } \\
\text { - room for walking } \\
\text { - untiring layout of } \\
\text { streets } \\
\text { - interesting facades } \\
\text { - good surfaces }\end{array}$ & $\begin{array}{l}\text { 5. Possibitites for } \\
\text { STANDING/STAYING } \\
\text { - attractive edges } \\
\text { sEdgeeffecte } \\
\text { - defined spots for } \\
\text { staying } \\
\text { - supports for staying }\end{array}$ & $\begin{array}{l}\text { 6. Possibilites for } \\
\text { SITTING } \\
\text { - zones for sitting } \\
\text { - maximizing advan- } \\
\text { tages primary and } \\
\text { secondary sitting } \\
\text { possibilities } \\
\text { - benches for resting }\end{array}$ \\
\hline & $\begin{array}{l}\text { 7. Possibilities to SEE } \\
\text { - seeing-distances } \\
\text { - unhindered views } \\
\text { - interesting views } \\
\text { - lighting (when dark) }\end{array}$ & $\begin{array}{l}\text { 8. Possibilities for } \\
\text { HEARING/TALKING } \\
\text { - low noise level } \\
\text { - bench arrangements } \\
\text { stalkscapese }\end{array}$ & $\begin{array}{l}\text { 9. Possibitites for } \\
\text { PLAY / UNFOLDING / } \\
\text { ACTIVITIES } \\
\text { - invitation to physical } \\
\text { activities, play, unfold- } \\
\text { ing \& entertainment - } \\
\text { day \& night and } \\
\text { summer \& winter }\end{array}$ \\
\hline $\begin{array}{l}\text { A } \\
\text { M } \\
\text { E } \\
\text { N } \\
\text { I } \\
\text { T } \\
\text { I } \\
\text { E } \\
\text { S }\end{array}$ & $\begin{array}{l}\text { 10. Scale } \\
\text { - dimensioning of } \\
\text { buildings \& spaces } \\
\text { in observance of the } \\
\text { important human } \\
\text { dimensions related to } \\
\text { senses, movements, } \\
\text { size \& behaviour }\end{array}$ & $\begin{array}{l}\text { 11. Possibilities for } \\
\text { enjoying positive } \\
\text { aspects of climate } \\
\text { - sun/shade } \\
\text { - warmth/coolness } \\
\text { - breeze/ventilation }\end{array}$ & $\begin{array}{l}\text { 12. Aesthetic quality/ } \\
\text { positive sense } \\
\text { experiences } \\
\text { - good design \& good } \\
\text { detailing } \\
\text { - views/vistas } \\
\text { - trees, plants, water }\end{array}$ \\
\hline
\end{tabular}

Figure 3: Jan Gehls quality criteria for good design of public spaces, protection, comfort and amenities. 


\begin{tabular}{|c|c|c|c|c|}
\hline $\begin{array}{l}\text { Fundamental } \\
\text { Human Needs }\end{array}$ & $\begin{array}{l}\text { Being } \\
\text { (qualities) }\end{array}$ & $\begin{array}{l}\text { Having } \\
\text { (things) }\end{array}$ & $\begin{array}{l}\text { Doing } \\
\text { (actions) }\end{array}$ & $\begin{array}{l}\text { Interacting } \\
\text { (settings) }\end{array}$ \\
\hline subsistence & $\begin{array}{l}\text { physical and } \\
\text { mental health }\end{array}$ & $\begin{array}{l}\text { food, shelter } \\
\text { work }\end{array}$ & $\begin{array}{l}\text { feed, clothe, } \\
\text { rest, work }\end{array}$ & $\begin{array}{l}\text { living environment, } \\
\text { social setting }\end{array}$ \\
\hline protection & $\begin{array}{l}\text { care, } \\
\text { adaptability } \\
\text { autonomy }\end{array}$ & $\begin{array}{l}\text { social security, } \\
\text { health systems, } \\
\text { work }\end{array}$ & $\begin{array}{l}\text { co-operate, } \\
\text { plan, take care } \\
\text { of, help }\end{array}$ & $\begin{array}{l}\text { social environment, } \\
\text { dwelling }\end{array}$ \\
\hline affection & $\begin{array}{l}\text { respect, sense } \\
\text { of humour, } \\
\text { generosity, } \\
\text { sensuality }\end{array}$ & $\begin{array}{l}\text { friendships, } \\
\text { family, } \\
\text { relationships } \\
\text { with nature }\end{array}$ & $\begin{array}{l}\text { share, take care of, } \\
\text { make love, express } \\
\text { emotions }\end{array}$ & $\begin{array}{l}\text { privacy, } \\
\text { intimate spaces } \\
\text { of togetherness }\end{array}$ \\
\hline understanding & $\begin{array}{l}\text { critical } \\
\text { capacity, } \\
\text { curiosity, intuition }\end{array}$ & \begin{tabular}{|l|} 
literature, \\
teachers, policies \\
educational
\end{tabular} & $\begin{array}{l}\text { analyse, study,meditate } \\
\text { investigate, }\end{array}$ & $\begin{array}{l}\text { schools, families } \\
\text { universities, } \\
\text { communities, }\end{array}$ \\
\hline participation & $\begin{array}{l}\text { receptiveness, } \\
\text { dedication, } \\
\text { sense of humour }\end{array}$ & $\begin{array}{l}\text { responsibilities, } \\
\text { duties, work, } \\
\text { rights }\end{array}$ & $\begin{array}{l}\text { cooperate, } \\
\text { dissent, express } \\
\text { opinions }\end{array}$ & $\begin{array}{l}\text { associations, } \\
\text { parties, churches, } \\
\text { neighbourhoods }\end{array}$ \\
\hline leisure & $\begin{array}{l}\text { imagination, } \\
\text { tranquillity } \\
\text { spontaneity }\end{array}$ & $\begin{array}{l}\text { games, parties, } \\
\text { peace of mind }\end{array}$ & $\begin{array}{l}\text { day-dream, } \\
\text { remember, } \\
\text { relax, have fun }\end{array}$ & $\begin{array}{l}\text { landscapes, } \\
\text { intimate spaces, } \\
\text { places to be alone }\end{array}$ \\
\hline creation & $\begin{array}{l}\text { imagination, } \\
\text { boldness, } \\
\text { inventiveness, } \\
\text { curiosity }\end{array}$ & $\begin{array}{l}\text { abilities, skills, } \\
\text { work, } \\
\text { techniques }\end{array}$ & $\begin{array}{l}\text { invent, build, } \\
\text { design, work, } \\
\text { compose, } \\
\text { interpret }\end{array}$ & $\begin{array}{l}\text { spaces for } \\
\text { expression, } \\
\text { workshops, } \\
\text { audiences }\end{array}$ \\
\hline identity & $\begin{array}{l}\text { sense of } \\
\text { belonging, self- } \\
\text { esteem, } \\
\text { consistency } \\
\end{array}$ & $\begin{array}{l}\text { language, } \\
\text { religions, work, } \\
\text { customs, } \\
\text { values, norms }\end{array}$ & $\begin{array}{l}\text { get to know } \\
\text { oneself, grow, } \\
\text { commit oneself }\end{array}$ & $\begin{array}{l}\text { places one } \\
\text { belongs to, } \\
\text { everyday } \\
\text { settings }\end{array}$ \\
\hline freedom & \begin{tabular}{|l|} 
autonomy, \\
passion, self-esteem, \\
open-mindedness
\end{tabular} & equal rights & $\begin{array}{l}\text { dissent, choose, } \\
\text { run risks, develop } \\
\text { awareness }\end{array}$ & anywhere \\
\hline
\end{tabular}

Figure 4: Human needs chart following Max Neef.

Many places have one or more defined functions, which influence their use. These can also change, depending on daytime or on the season. A space can mainly be a completely abandoned car park, which, for a few hours per week, turns into a very lively mart. It does not require any seating furniture; all the people are just standing in front of the stands.

The criteria also change by the subjective perception of each individual person. The tightness in a shopping street during Christmas/in a restaurant street during the summer, can be perceived as negative as well as positive.

The list of criteria derived from the student's contributions is now presented here. It consists of four sections:

1. To feel safe and be able to concentrate on the positive side of life.

2. To take advantage of the offers - requirements for the appropriation of the space.

3. To experience - passive and active appropriation of the space.

4. To enjoy.

Each section is separated into different subsections ranging from $\mathrm{A}$ to $\mathrm{K}$ and these contain the intrinsic criteria, summing up to 79 .

Another finding was that there are different qualities of criteria. Some were recognized as necessary, without them the space would not (or hardly) be possible to function.

Complementary criteria can increase the liability of some spaces remarkably but are not a general precondition for all spaces. They are added in italics. 
Table 1: First section of criteria list: to feel safe and be able to concentrate on the positive side of life.

Feel safe against traffic and accidents

1) Protection from all kind of transport 1 2) Clear partition of the recreational areas traffic (cars, bikes, pedestrians)

A. Feel safe against robbery and violence

3) Busy public space ("many eyes on the 18 ) In case of emergency other people are spot")

4) Clearness of the personal safety-zone

5) Means of escape

6) Equal use during day and night

7) Good lighting at night

B. No unpleasant perceptions

12) Wind, rainfall, (too much) sun

13) Dust, odour, dirt

14) Garbage

15) Wild urination

16) Drug consumption and dealing reachable

9) Video cameras

10) Police station not far away

11) Emergency call station

Table 2: Second section of criteria list: to take advantage of the offers - requirements for the appropriation of the SPACE.

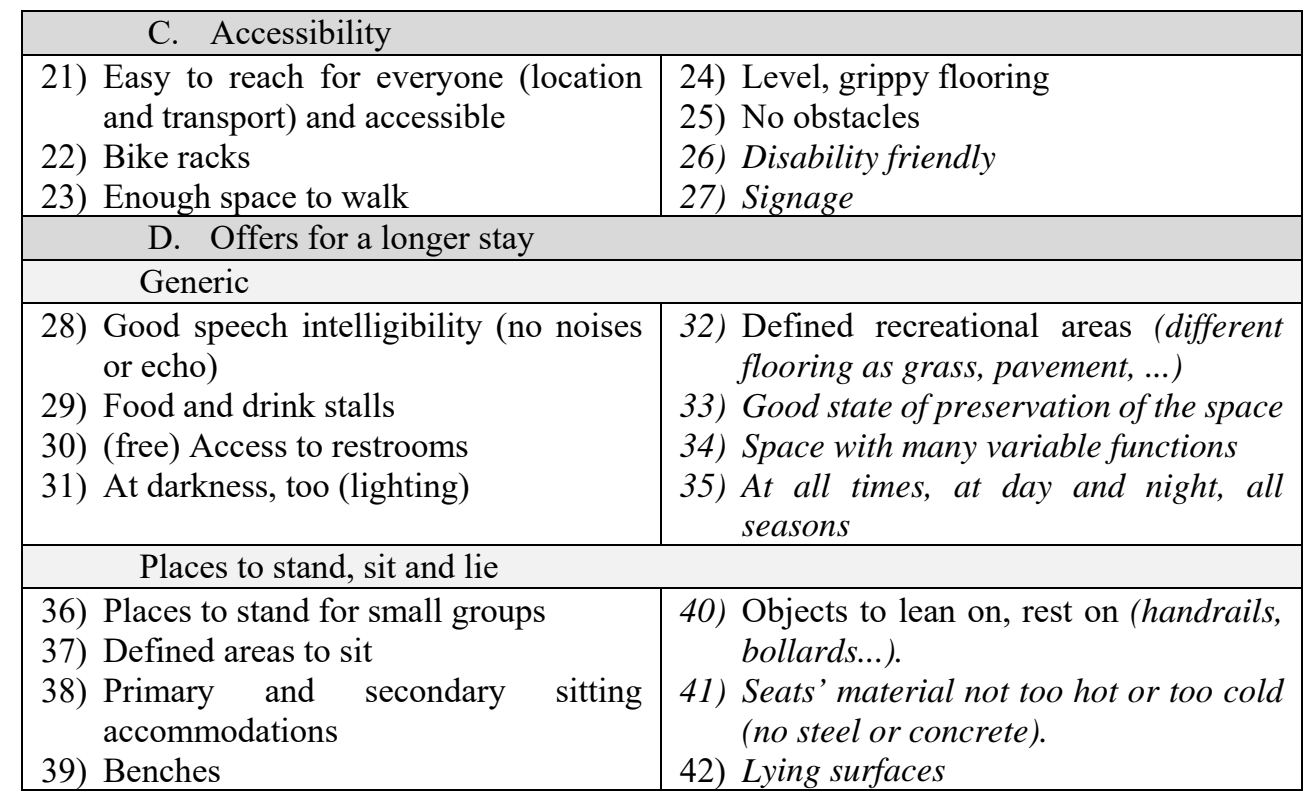


Table 3: Third section of criteria list: to experience - passive and active appropriation of the space.

E. Places for undisturbed observations

43) Observe without having the feeling to be seen

45) Visual axes and outlooks

46) "Forbidden" places (not made for

44) One or more vertical shielding surfaces ("wall in the back") observation: quay walls, rooftop terraces....)

F. Places for communication

47) Offers for socially different groups

48) Offers for different times of the day

50) Topographic situation (terraces, dams, and of the year

49) Communicative collocation of the seats (large benches, collocation around corners, etc.)

G. Places for active and passive appropriation

51) Movable elements to sit or lie on, to shadow etc. self-defined arrangements

52) Sufficient space for moving

53) Architectural elements as incentives for creative activities, movement, games and sports

54) Offers for children

55) Places for playing, physical (chess board on the square, on tables) or virtual

57) Weekly market, flea market

58) Places which permit the residents' and users' initiatives (chair in front of the door, own pillows, barbecue, planting flowers, drawing playgrounds, neighbourhood parties, etc.)

59) Places for education: bookshelves, static or interactive info-boards

60) Staging of an attractive lighting at night

61) Open-air cinema, big video screens

56) Street-art: theatre, concerts, performances, artists

Table 4: Fourth section of criteria list: to enjoy.

\begin{tabular}{|c|c|}
\hline \multicolumn{2}{|l|}{ Human scale } \\
\hline $\begin{array}{l}\text { To find one self's measurements in the } \\
\text { surrounding space and buildings }\end{array}$ & To feel secure \\
\hline \multicolumn{2}{|l|}{ Pleasant climatic situation } \\
\hline $\begin{array}{l}\text { Be able to enjoy the pleasant side of the } \\
\text { prevailing weather conditions } \\
\text { Sun or shadow }\end{array}$ & $\begin{array}{l}\text { Sheltered from the wind or light breeze } \\
\text { Warmth or cold }\end{array}$ \\
\hline \multicolumn{2}{|l|}{ Positive sensory impressions } \\
\hline $\begin{array}{l}\text { Nice views } \\
\text { Haptically and visually pleasant materials } \\
\text { Well-made design } \\
\text { People playing or talking to each other (children } \\
\text { and adults), "Human Theatre" } \\
\text { Natural and local materials } \\
\text { Trees, green areas, (burbling) water }\end{array}$ & $\begin{array}{l}\text { Fragrance (flowers, sea....) } \\
\text { Particular historical / urban context } \\
\text { Identity, uniqueness of the space } \\
\text { Artworks } \\
\text { Animals } \\
\text { Education and entertainment }\end{array}$ \\
\hline
\end{tabular}




\section{EXAMPLES FOR SELECTED CRITERIA}

\subsection{Crowd - Nr. 19}

A public space can be influenced negatively by its own success, attracting large crowds (see Fig. 5).

5.2 Offers for children - Nr. 54 and places for playing, physical (chess board on the square, on tables) or virtual - Nr. 55.

A public space, a stick of chalk - and children can play hopscotch (see Fig. 6). Observing adults would enjoy watching them play.

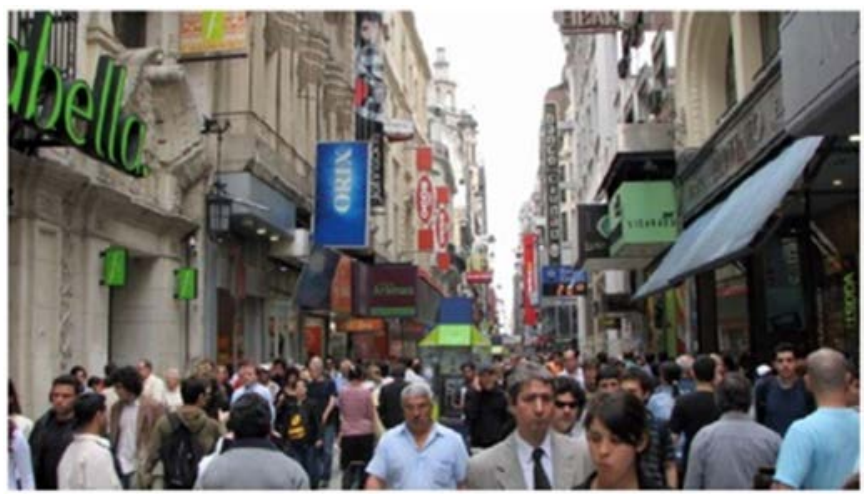

Figure 5: Calle Florida in Buenos Aires, crowded by its own success [8], [9].

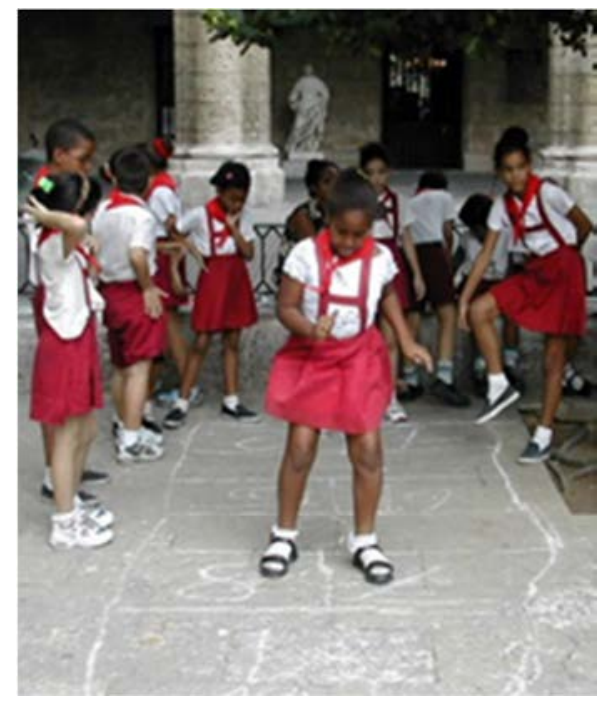

Figure 6: Children playing hopscotch in Havana, Cuba [10]. 
5.3 Topographic situation (terraces, dams, little slopes) - Nr. 50

A smooth topographical design and layout allows the possibility to watch from the top or to be protected (from wind, views of other people, sun etc.) in lower levels (see Fig. 7).

5.4 Staging of an attractive lighting at night - Nr. 60

A public space is more attractive during night if an interesting illumination is enacted (Place Massena, Nice, Fig. 8).

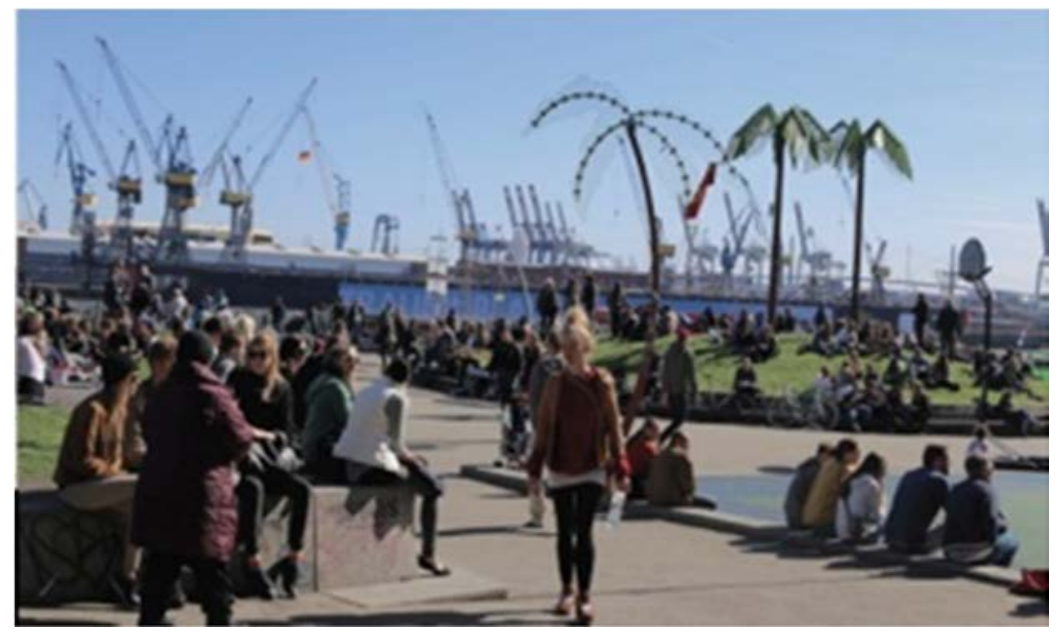

Figure 7: Park fiction in Hamburg, Germany. A smooth topographical situation invites to stay and to watch [11].

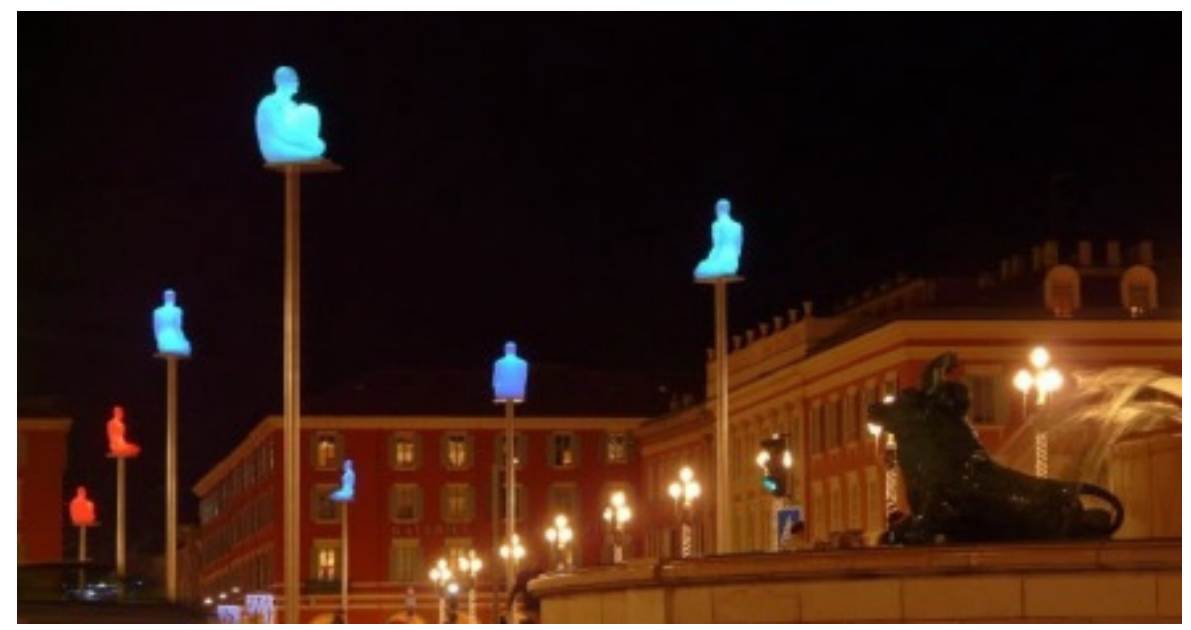

Figure 8: Sculptures on Place Massena in Nice become lively during night, they change colors. 
5.5 Sun or shadow - Nr. 65

Especially in hot and sunny locations, shading devices are used as protection elements from the heat (see Fig. 9). Shadow is an important aspect, mentioned as a central criterion to enjoy the weather. Otherwise sunny and wind protected places would be preferred in colder climates.

\subsection{Water - Nr. 73}

Water is a highly desired attraction for children and adults. Especially if it is lively and walkable (see Figs 10 and 11).

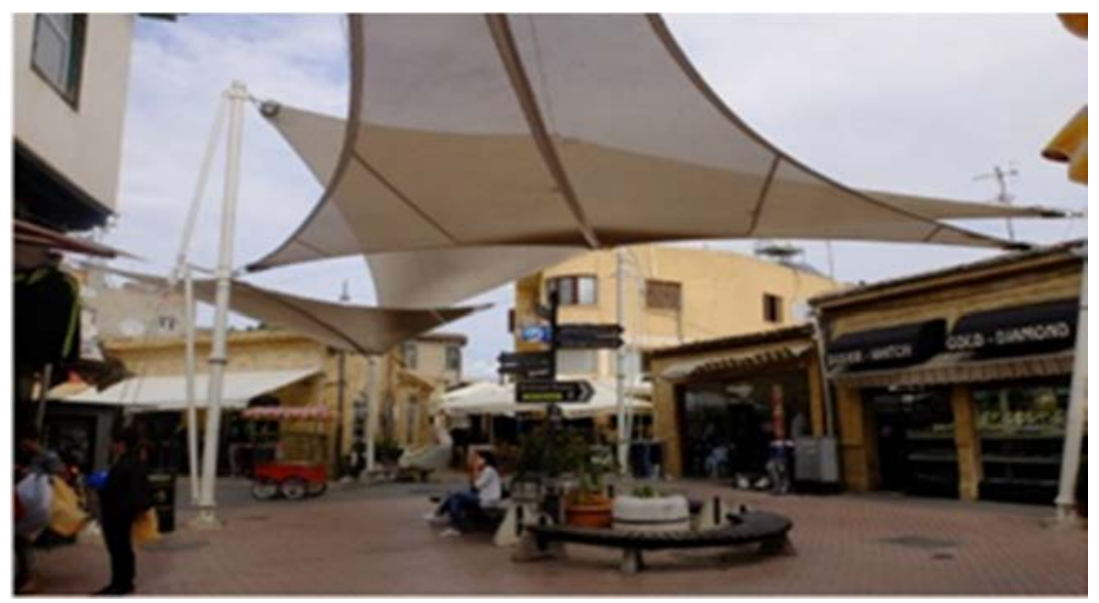

Figure 9: Pedestrian zone in Nikosia, Cyprus. Fabrics cover the street to spend shadow and protect people from sun [13].

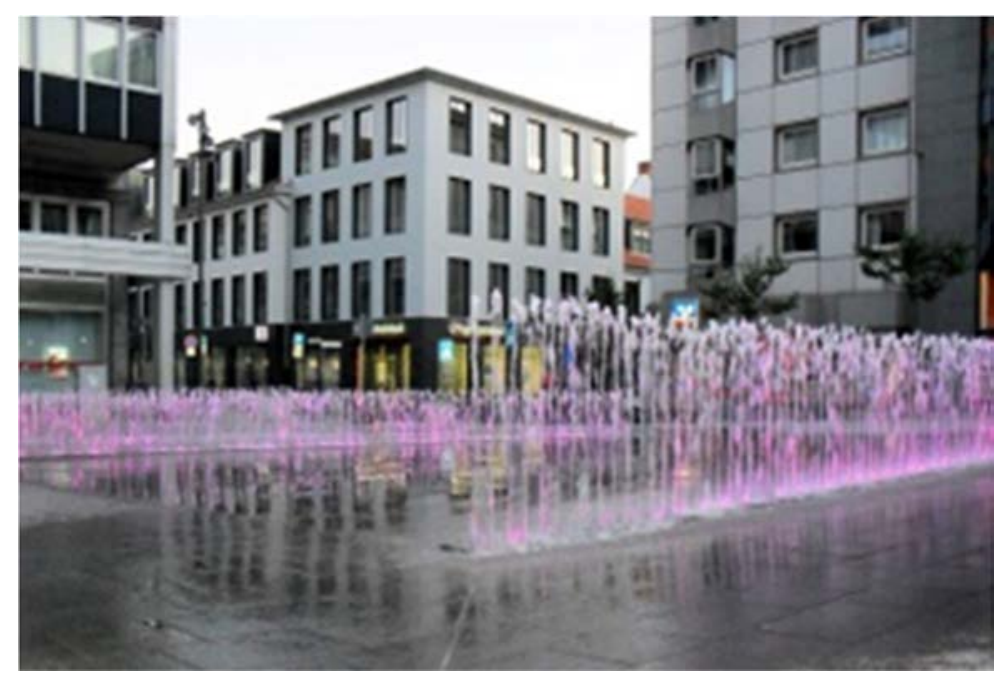

Figure 10: Wasserspiele, Luebeck, Germany [15]. 


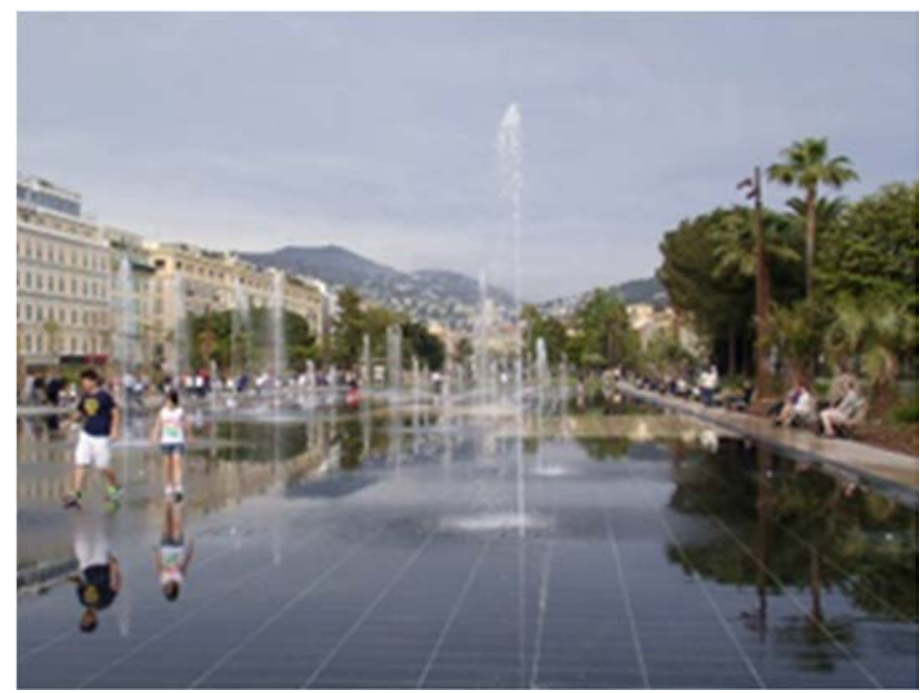

Figure 11: Promenade de Paillon, Nice, France [14].

\section{FURTHER ASPECTS INFLUENCING THE ATTRACTIVENESS OF A PUBLIC URBAN SPACE}

\subsection{Dominant positive aspects}

A positive perception can dominate a negative one. For example, sites like airports, railways and industrial facilities can become attractive when negative aspects such as noise and smell are not perceived because of a great distance.

Fig. 7 shows a typical situation where the view to a port becomes attractive because of a bigger distance protecting from unpleasant sensual perceptions.

\subsection{Other cultures}

The presented criteria are a product derived from investigations in developed 'westernoriented' countries. Unconsciously it is a mirror of this culture.

In order to apply it to other cultures the rules must be adapted respectively, especially in regard to communication, safe distances and enjoyment.

For example, drivers of vehicles with different velocities communicate with each other as well as they do with pedestrians. They create a safe atmosphere on the base of bilateral respect, even without a clear separation of traffic zones and areas to stay. The aspect of speed is much less important here.

\section{CONCLUSION}

The criteria are highly recommended for further use in designing and planning of urban places. Thus, the list should be further developed, basing on own experiences. The criteria should also be adapted to different conditions in regard to location, climate, culture. 


\section{REFERENCES}

[1] Baker, N., We are all outdoor animals, PLEA Conference, Proceedings, pp. 553-55, James \& James, London, 2000.

[2] Residential buildings in Chaoyang District, Beijing, https://commons.wikimedia.org/ wiki/File:Beijing northeast.jpg. Accessed on: 18 Jan. 2017.

[3] Piazza del Campo, Siena, picture U. Dietrich, 2016.

[4] Gehl, J., Life between buildings: using public space, 1987, New York, Van Nostrand Reinhold

[5] http://www.onthecommons.org/magazine/12-steps-creating-communitycommons\#sthash.GPwsuWZT.dpuf. Accessed on: 18 Jan 2017.

[6] Dietrich, U. \& Kengyel, N., "What makes a public open space liveable?", WIT Transactions on Ecology and the Environment, 204, 2016.

[7] http://www.rainforestinfo.org.au/background/maxneef.htm. Accessed on: 19 Jan. 2017.

[8] https://utta2010.wordpress.com/2011/12/13/florida-entre-el-brillo-y-la-decadencia/. Accessed on: 20 Jan. 2017.

[9] Callau Poduje, P., Human body and human Scale, MA course, Hafencity University, 2016.

[10] Von Hopscotch_de_Cubanese.jpg: James Emery from Douglasville, United States derivative work: Dcastor (talk) - Hopscotch_de_Cubanese.jpg, CC BY 2.0, https://commons.wikimedia.org/w/index.php?curid=10276154. Accessed on: 20 Jan. 2016.

[11] Biber, C., Human body and human Scale, MA course, Hafencity University, 2016.

[12] Place Massena, Nice, C., Bontemps, https://commons.wikimedia.org/w/ index.php?curid=3986822. Accessed on: 20 Jan. 2017.

[13] Biber, C., Human body and human Scale, MA course, Hafencity University, 2016.

[14] Promenade de Paillon, Nice, picture U. Dietrich, 2016.

[15] Von Der Bischof mit der E-Gitarre at de.wikipedia, https://commons. wikimedia.org/w/index.php?curid=16607682. Accessed on 20 Jan. 2017.

[16] Kirchberg Erto, G., Human body and human Scale, MA course, Hafencity University, 2016.

[17] Hamburg City Nord. https://www.sugarraybanister.de/hamburg/hamburgimpressionen-3-city-nord. Accessed on: 4 Dec. 2016.

[18] Kirchberg Erto, G., Human body and human Scale, MA course, Hafencity University, 2016. 